\title{
SOME OBSERVATIONS ON LAW AND PSYCHOLOGY*
}

\author{
DAvin RIESMAN $\dagger$
}

Introductory comment. Mr. Riesman's remarks bring up what is perhaps the central psychological problem of a large number of occupations: the fact that people who practice them deal routinely with the emergencies of other people. The reason I go to a professional with my emergency is that I know he has treated hundreds of others just like mine. In order to treat "unique" emergencies like mine by the hundred, one must be cool and objective about them. The "unique" emergencies must be classified, since diagnosis is essentially classification. But if I take my troubles to a professional just because he is objective about them, I suspect him for the same reason. It is not nice of him to put my problems concerning ownership of my one dearly bought house or the solvency of my one and only business into a category and to coldly compare strategies for assuring the outcome I would like as against the one I wouldn't like. It is said that prostitutes are frequently turned upon angrily by customers to whom they have just given very competent service; this might be because of guilt, but it might also be because of chagrin at the thought that she has sized him up and put him into a category in relation to her numerous other customers. The customer, in short, is quite ambivalent about the objectivity of the people whom he hires to deal with his emergencies. Mr. Riesman's paper is full of implicit reference to this problem.

Now this problem cuts both ways. The professional has to deal with his own objectivity, and to keep it in that delicate balance which allows him to get fun out of his work by looking upon his cases as works of art, but yet keeps him practical enough to be of service to the client, both because of the common human motivation to do so, and because one must do so to eat. Herein lies the answer to the riddle: why does the professional take the subject matter of his work, e.g., the legal troubles of other people, both less seriously and more seriously than the client? He takes it less seriously, even jokes about it in a macabre way, so that it will not get him down to be unemotional about the things that laymen are emotional about. The lawyer knows that the cult of the law is a cult; that its ritual really is ritual, and can be kidded. But, on the other hand, he takes his objectivity and his levity dead seriously, and will fight to the death

* Remarks at a Round Table on Law and the American Mind, under the chairmanship of Professor Albert Ehrenzweig, Association of American Law Schools, meeting of December 29, I950.

$\dagger$ Professor of Social Sciences, College of the University of Chicago, and member of the New York bar. 
for the right of himself and his colleagues to be objective and cool about the legal emergencies of others. So maybe the professional mind is the opposite of a volcano, a cold core of objectivity surrounded by a fiery wall of defensive rationalization. In short, the professional mind is a kind of perversion of the lay mind. Where the one is hot the other is cool. It may be, incidentally, that the lay world is more suspicious of those who are objective (professional) about justice than about those who are merely objective about the body (as are physicians).

I do not know the facts concerning democracy in the law schools and concerning sponsorship into good careers. Sponsorship in medicine is certainly strong, and there are those who say it is important in the academic career. American culture has stressed individual effort and ability, but never to the exclusion of family, class, religious and ethnic affiliations. We have had a kind of mixture of nepotism with insistence on delivering the goods. It may be that the law, or certain branches of it, demands abilities less amenable to social inheritance than those which make people company presidents. At any rate, $\mathrm{Mr}$. Riesman has raised questions for studies of the law and lawyers far more penetrating than that which conventionally has been done as psychology or sociology of law.

Everem C. Hughes*

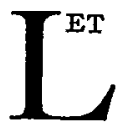

ET ME TAKE as a starting point some remarks from Llewellyn and Hoebel's The Cheyenne Way, which has been for me the most exciting book ever written about the social and psychological meanings of law:

Thus each law-job, and all of them together, presents first of all an aspect of pure survival, a bare-bones. The job must get done enough to keep the group going. This is brute struggle for continued existence. It is the problem of attaining order in the pinch at whatever cost to justice. But beyond this, each job has a wholly distinct double aspect which we may call the questing-aspect. This is a betterment aspect, a question so to speak of surplus and its employment. On the one side, this questing aspect looks to more adequate doing of the job, just as a doing: economy, efficiency, smoothness, leading at the peak to aesthetically satisfying grace in the doing of it. On the other side, the questing aspect looks to the ideal values: justice, finer justice, such organization and such ideals of justice as tend toward fuller, richer life. It no more does to forget the bare-bones in favor of these things than it does to forget these things in favor of the bare-bones. ${ }^{x}$

I propose to embroider on these sentences by pointing to certain other purposes which law may serve in American society, both for lawyers and

* Professor of Sociology, University of Chicago.

Llewellyn and Hoebel, The Cheyenne Way 292 (I94r). 
for the public at large. But before doing so, I should point out that we know far more about the law-ways of the Cheyenne (or the Andaman Islanders or the Trobrianders) than about those of any complex industrial society. As lawyers, we know our shop only from within, and although Thurman Arnold, Fred Rodell, and other welcome peddlers of irreverence have tried to debunk some of the myths of the profession, they have tried less hard to understand them sympathetically and to see their function.

Social scientists, except for a few intrepid ones like Robinson, ${ }^{2}$ have not sought to understand law as an institution-in terms of the personality needs it creates and satisfies, as against concern with the quality of its social performance. Rather, law and psychology have mingled only at their peripheries. They have had, for instance, a jurisdictional dispute over criminals and crime, each group finding something to write or fuss about in the M'Naghten rule. They have argued, again peripherally, over the rules of evidence and their psychological soundness or idiocy. There has been some discussion, greatly stimulated by Judge Jerome Frank, about the psychology of trial and appellate judges and of juries. But these meeting grounds are rather like the parlor in the Victorian home in which the girl and her suitor can get together-but not get together too much.

We simply do not have any adequate knowledge of the type of questions raised in The Cheyenne Way. What is the role of reasoning in our society, and of legal reasoning as an institutionalized form? What is the role of the legal profession in draining off certain kinds of people and providing them with myths, agendas, and rituals which may or may not be otherwise significantly related to the function of law in the society at large? What is the relation between the various types of career lines pursued by lawyers and the mobility aspirations of various class and ethnic groups? To what degree does the lawyer, or certain kinds of lawyers, play the role of scapegoat, among businessmen, or farmers, for example; and how does the lawyer protect himself against the judgments, demands, and emotional crises of his clients? And so forth and so on. Those to me are the interesting questions, hardly touched, and not likely to be, so long as the relations between law and psychological approaches are marked off by high defensiveness on both sides-on the side of the lawyer because, as Everett Hughes has been observing, no profession really likes to be studied (apart from the public relations value of being prominent enough to have studies made), ${ }^{3}$ and on the side of psychology because the law has succeeded, as

2 Robinson, Law and the Lawyers (I935).

${ }^{3}$ See, e.g., his article Work and the Self, in Rohrer and Sherif, Social Psychology at the Crossroads (I95r) at 3 I3. 
few professions have, in convincing social scientists that it is a formidably difficult affair. As Judge Frank remarks in Courts on Trial: "We have progressed at least this far beyond our early predecessors: We have a label, 'psychology,' for a mass of difficult problems." 4

All I can do in this paper is to throw out some possible leads for investigation, because before we can get further than programmatic statements we need some detailed studies of The Cheyenne Way sort.

Let us, for instance, develop the scapegoat theme. We might take a look at Veblen's charge that the lawyers are engaged in what he called the archaic, pecuniary, and predatory employments, in the same class with bankers, as against the matter-of-factness of engineers and skilled workmen. My own experience has been almost the opposite: that it is lawyers who are apt to be matter-of-fact about human relations, where engineers are apt to have an archaic, pecuniary, and otherwise myth-ridden outlook. And this is not surprising, for the better law schools have for a generation or more been training their students in the art of debunking legal rituals and debunking authority, especially the authority of upper-court judges. More generally, lawyers learn something about relevance, a concept which, to their constant frustration, seems nearly absent in most of the people they deal with. Above all, lawyers learn not to take the law too seriously. Thus they are prepared for a role as a person who, to quote a recent observer, "either knows all there is to know about judges, public officials, business leaders, bankers, professional politicians, labor leaders, newspaper publishers, leading clergymen, and the like; or through that informal clearing house of esoteric information, the bar association, can find out from colleagues." 5 But the layman is not quite sure how he feels about such a person, whose usefulness he may need and whose knowledge may fascinate him; the more he needs him, the more he may be apt to project on to him his own tendencies to cynicism about authority and procedure.

At the same time, there are other elements of the lawyer's career line which lead him to willingness to accept the role of red-tape cutter and redcarpet debunker. Law schools are supposed to be hard, so they attract the more ambitious, the more mobile young people. Lawyers tend to become hard-working isolates; they are less inclined than the average client to be or appear to be "big hearted," "good guys," and so on, the vocabulary by which they would be seduced into accepting the normal archaisms of the business world. They are, in other words, paid rate-busters, mobile men

4 Frank, Courts on Trial 47 (I949).

5 Lundberg, The Profession of the Law, 178 Harper's I, Io (Dec. I938). 
in every sense, who find in devotion to their profession and in the respect of their professional colleagues rewards for serving clients in ways the clients do not entirely approve and, what is more, do not want to have to approve. While it is usually thought that lawyers are particularly partisan people (and to be sure this is sometimes so) they are less partisan than non-lawyers, as every client realizes when he sees the fraternizing of opposing counsel. They are, I may suggest, a particular breed of men who can tolerate a certain amount of hostility brought upon them for the disrespect of the public's image of the law they must show in order to get the public's work done.

In certain situations, however, the client cannot tolerate non-partisanship even when it is clearly in his interest. There have been cases of quite conservative but unfanatical lawyers, accustomed as few engineers are to taking account of human stresses and strains, who have lost their jobs as labor negotiators because management wanted, not success in the labor bargain, but a ritual of expletives against those "damned union bastards." Sometimes businessmen and others dealing with the government have been similarly unwilling to accept their lawyers' matter-of-factness; they have wanted to pay, not for success, but for resounding speeches. And since they could find members of the bar who would do this for them, they were deprived both of their success and of their comfortable assurance that they were morally superior to lawyers. Sometimes, as Everett Hughes has observed, this problem is handled by symbiotic teams of lawyers, one matter-of-fact, the other a ham actor. (We may be in a similar situation today with respect to the demands we make on our diplomats-men, of course, often trained in the law.)

It will be interesting to see to what extent the demand for partisanship, on the one hand, and the perhaps increasing psychological need for lawyers to be liked by their clients on the other, will actually destroy a good deal of the lawyer's usefulness. We must ask, for example, whether it is really a good idea to train lawyers in psychology, if the effect of this is to make them more sensitive to their clients' moods and judgments, more "otherdirected," or to break down the psychological defenses of the "secret society."7 Perhaps the lawyer, or a certain kind of lawyer, has to be a person with a thick skin, not very interested in how other people feel or in how he himself feels. To put this another way, if he should become very

${ }^{6}$ For further discussion of psychological "other-direction" and its relations to the lawyer's career, see Riesman (with the collaboration of Denney and Glazer), The Lonely Crowd: A Study of the Changing American Character, c. 6 (1950).

7 Cf. Simmel, The Secret and the Secret Society, in The Sociology of Georg Simmel, pt. 4 (Wolff trans., I950). 
much concerned with others' feelings, might he not become merely a competitor with another kind of client-caretaker, namely the public relations man? While to be sure many public relations men are lawyers, can the law schools eventually do as good a job in training this crew as, let us say, schools of journalism do? This takes us into difficult questions of competition among (rather than within) professions.

Let us move back, in regard to this question, to the interesting observations which many of you must have made that most lawyers, and law school students, and perhaps law professors too, want to be judges. Now, in a way this is curious, since the greater part of law school time is spent in debunking and criticizing judges, especially appellate judges, showing them to be men who, much like a Hollywood producer, have to "edit" the script of a trial record in order to show that they are indeed mighty men. It seems to me that this paradox is not so much explained as illuminated by the fact that the heroes of the bar are mostly judges, instead of the inventive, but often anonymous, corporate lawyers who developed our modern corporate system with such extraordinary zeal and imagination-an imagination matched by very few judges. Law school students often disapprove of corporate lawyers of this sort; they idolize men of the robe whose pronouncements are a matter of record, often eloquent, and only occasionally imaginative. Why this narrow galaxy of heroes? Sometimes the constellation includes no more than Holmes, Brandeis, Cardozo, and someone from the Second Circuit. Is this connected with the lawyer's scapegoat role and a desire to climb above it at some point in one's lifea desire remaining unaltered by later experience as a practicing lawyer which even increases one's cynicism about judges and one's doubts as to whether they ordinarily play any creative part comparable to that of the practitioner? Is it a symptom of the "Langdell [ivory tower] neurosis" that Judge Frank berates in Courts on Trial, ${ }^{8}$ or is it rather connected with the image of the law which led the more idealistic students to go to law school in the first place? However that may be, the pull of the robe is a tremendously powerful one, as every government official knows who has tried to give a congressman's law partner the ersatz of an I.C.C. post as against a district judgeship; and, as Tammany and other city machines know, more work can be obtained for a judgeship than for almost any other gift in their power. ${ }^{9}$

8 Op. cit. supra note 4 , at $225-44$.

9 It is not surprising that the public at large shares the lawyer's reverence for the judge. On a poll of occupational prestige, United States Supreme Court judges were rated highest; and the Supreme Court decision on racial covenants served to overawe a bunch of white Chicago hoodlums who had not been impressed by any other form of pro-tolerance propaganda. But what 
Let us turn now to another group of functions served by lawyers and the law, namely the functions of ceremonial and periodic festivity. Those social scientists who term the United States a secular culture and bemoan the passing of what they call "sacred symbol systems" sometimes fail to see that seemingly secular institutions often serve much the same function served by shamans or sorcerers in preliterate tribes. For one thing, court sittings are seasonal affairs; in most places they are not like a store or bank which is open for business all year long. To be sure, this festivity function is declining, but we can still see its outlines in such a book as James Gould Cozzens' The Just and the Unjust or the anthropologist James West's Plainville, USA. ${ }^{\text {xo }}$

Plainville is the pseudonym of an Ozark town as yet relatively untouched by modern mass communications, and the court's sittings have prime value in breaking the monotony of everyday life and linking people together in communal affairs. West describes a couple of trials; one in which Hobart Proudy was charged with shooting his cousin Mort Proudy in the seat of his britches with both barrels and a witness testified that Hobart should be let off because "if he had intended to kill Mort, he would have, since Hobart won't shoot a squirrel down out of a tree, anywhere except in the eye"; another, an adultery suit between the undertaker and the garagekeeper over the latter's wife, kept the atmosphere electric for several months. West observes that the law is very ambivalently regarded in Plainville: it is at once feared and enjoyed, regarded as a threat and regarded as a show; this complex of emotions gives the court its high position in the ceremonial life.

If we try, however, to push our problem further and to see just what elements lie behind our attitudes towards law, we run into psychological questions of great subtlety on which I do not feel that I can shed much light. As Reinhold Noyes and other students have pointed out, the relations of men to property, to things, is one very important theme; these relations, as you all know, come down at bottom to relations among men about things, rights in rem being a creation of the social order. Let me illustrate this by an experimental psychodrama. (A psychodrama is a playlet in which people play roles whose barest outlines are assigned to them.) This one was developed by the Veterans' Administration to test candidates for VA jobs in terms of the amount of aggression they possess. One of the testers plays the role of a Chinese laundryman who cannot

is surprising is that the lawyers themselves have this reverence, when they know, for example, how little freedom they allow judges in this country to have vis-à-vis the jury and contending counsel.

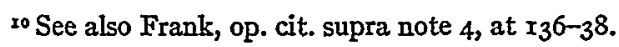


speak English. The candidate being tested is told simply that his tuxedo has been left at a laundryman's, that he needs it for a big date at seven P.M. and that he will see his tux hanging, fully pressed, behind the counter. The following is a typical conversation:

Candidate: "Here is my claim check; there is the suit hanging there."

Laundryman: "Don't speak English. Boss back at 7."

C. "But I need this before 7. There it is."

L. "Don't speak English." (Sits down behind counter and picks up paper.)

C. (Hesitates, moves towards the counter.)

L. (Lowers paper, looks up.)

C. (Halts.)

L. (Raises newspaper.)

C. (Starts to cross counter.)

L. (Rises, says nothing.)

C. (Gives up and leaves, but in two cases only): "God damn it, give me my suit." (Grabs it and leaves.)

Our own problem here is not so much the question of aggression (though this has been of great interest as it bears on law, in the thinking of Malcolm Sharp and other writers) as in the question: what is the counter made of? There is no reason to assume that the counter is simply a culture barrier between Chinese and Americans. Rather, the counter seems to be made of some kind of interpersonal field situation connected with property rights and nuances of trespass. In this dance of interpersons, a line is drawn between the suit and its owner by some of the same considerations which created the relation between owner and tuxedo in the first place.

At any rate, I am sure I don't understand all that is involved in this experiment; but it may serve to illustrate a further point I would like to make, that psychology has as much to gain from studying the operation of law as law has to gain from greater appreciation of psychology. This is obvious but is perhaps sometimes overlooked by those lawyers and law professors who are concerned primarily with expanding their own horizons and do not see how much they might teach social scientists in search of some of the most important themes of our culture. Having now moved over into social science, I find a tendency among some of my new colleagues to overestimate the importance in the social structure of individual personality factors. This overestimation might not come so readily if one has studied, as lawyers must, the long historical development of an institution which has proceeded to some degree in its own luxuriant growth without becoming entirely the product of the personalities of those who fill its roles and perform its duties at any given historical period. ${ }^{\mathrm{xx}}$

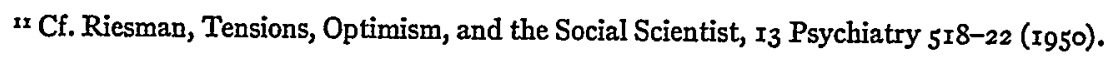


Perhaps I can indicate what I am trying to get at by drawing on my observations when I served a term in the Appeals Bureau of the New York District Attorney's office. What struck me there was the fantastically non-utilitarian character of the briefs we wrote. My boss, Stanley Fuld, was a law review trained man who felt that no case was too humble to be loaded with all the erudition and art of brief-writing the whole office could muster. There were open and shut gambling cases, for example, (this was Mr. Hogan's particular crusade in those days) where our brief would draw, not only on Hawaii and the law reviews, but even on New Zealand reports and perhaps something from the French Court of Cassation! Now, who was the audience for this display of professional activity? It was not a make-work ritual in the sense of James Caesar Petrillo, not only because we were all high-minded men but because we were in fact short-handed and were actually more likely to lose men and even funds than to gain them by these tactics. Our tactics were certainly not appreciated by the trial lawyers who ridiculed us as some kind of fanatical brain-trust, pointed out, as we well knew, that we won 98 per cent of our appeals anyway and that most of the judges didn't, or perhaps couldn't, read briefs. Nor did we endear ourselves to defense counsel, often barely literate and often much too impecunious for such displays of irrelevant learning. Nor did our briefs come to the attention of members of prominent downtown firms, who might appreciate our standards and hire our people, for such members enter the criminal courts only, so to speak, by proxy.

Thus, after eliminating all rational explanations for our activity, I concluded that we deal here again with some sort of secularized religious activity by which the members of the Appeals Bureau exploited a long tradition of legal learning in order to lend meaning to their daily lives. On the face of it, these lawyers were worldly men, or at least worldly-wise; in their unconscious, motives of an unworldly sort operated which they would have done their best to deny. Perhaps something of what Veblen called "the instinct of workmanship" was at work here-some desire to do a good job in some transcendental sense. These non-utilitarian elaborations go on in the law (I don't consider our office unique, though it may have been extreme) not in search of justice, but in search, as the quotation from Llewellyn and Hoebel's book would imply, of something which transcends even justice, some kind of quest, some kind of "art for art's sake." Indeed, I am fairly sure that something of the same sort happens in all professions, but the lawyer is perhaps less able than others to conceal his intellectual orgies! They are often a matter of record, or they exist in filing 
cabinets. The lawyer's sense of relevance, often greater, I have suggested, than that of other people, must constantly struggle with his desire to use his very rationality for ends he cannot admit to himself. And this in turn may link up with the ambivalent role of the lawyer in our society, who stands at once for reason and for an excess of it.

An attempt, then, to write the many-volumed Cheyenne Way which we would like to have for our own society operates with the great advantage of the relative visibility and recorded quality of many legal actions. But in one way this is a disadvantage, or has been so far. For the psychologist who wishes to understand the role of lawyers and the law has to trespass across the Chinaman's counter, if he wants to get beyond both these generalizations about the unreasonableness of the law and these peripheral touchings at the most obvious points of criminal justice and trial psychology. He needs to wade into the lawbooks themselves, and into law files, as well as to observe, as James West did, the ceremonial and festive functions of Ozark court sessions. He has to sit in on sessions between lawyer and client, especially lawyer and corporate or governmental client, to see if he can observe ways of thinking that are peculiarly legal. Maybe he will have to make distinctions not only between various kinds of law practice, but between various groups of law school graduates. It is hard to imagine graduates of some schools, for instance, carrying to the courts at their client's expense as a real crusade an effort to prove Williston right as against Corbin, or vice versa, as I am told some Harvard and Yale graduates in big New York firms have done. At the same time, the law teacher may discover that the first and easiest place to observe these tendencies of the American legal mind in the making is in the classroom, on the law review, and in the social life and the myths of the law students. Certainly a good place to begin any serious investigation of the kind of problem I have outlined here is to follow the development of the law student who enters law school already possessing a kind of legal culture and personality, and to see what happens as he goes through the rites of legal education.

Let me turn for an illustration of this last point to a few remarks about that most remarkable institution of the law school world, the law review. So far as I know, there is nothing in any other professional group which remotely resembles this guild of students who, working even harder than their fellows, manage to cooperate sufficiently to meet the chronic emergency of a periodical. Indeed, this cooperation often develops an island of teamwork in a sea of ruthless rivalry. Law review students frequently have a note-taking agreement, so not all have to attend class; and in other 
ways they are likely to cover for each other in dealing with the obstacles to their review work, and often enough to their education, that the curriculum offers.

To be sure, the major law reviews have a rather amiable rivalry inter sese, as the boards of editors on the older reviews have a rather amiable rivalry with the records set up by earlier and deceased boards of editors. But there is little that is factitious about this school spirit; it is not whipped up by coaches (though here and there faculty advisors, public-relations conscious, may play this role) or by cheer leaders, but is self-perpetuating. The resulting standards often become so high that the contributed articles by law teachers and practitioners are markedly inferior to the student work both in learning and in style and, in fact, often have to be rewritten by the brashly serious-minded student editors. * As democracy based on ability to do something (rather than that spurious democracy which is based on ability to be a right kind of guy) is strongest in the high schools and colleges in the field of sports, so in the professional world it appears strongest in the competitive-cooperative teamwork of the law reviews.

For it is a notable feature of this teamwork that it is based on impersonal and objective criteria in the sense that it ignores social class and ethnic lines and, beyond these, "personality" above a bare minimum. In many law schools, election is not really election, for it is based on grades alone; in others, it is based on performance, judged almost as impersonally as the grades themselves are judged by the scrupulous fairness of the faculty. (It is perhaps no accident that one or two law schools, as at Yale and Chicago, contain some of the most fervent devotees of Henry Simons' utopian vision of a free, impersonal, unmonopolistic economy; law reviews are the very model of such an economy, a model which it would be hard to duplicate elsewhere in the society.) I think that studies might reveal that, not only cooptation to the law review, but the election of officers thereupon, is heavily influenced by an ideology of impersonal, objective performance in which "merely" social and ethnic considerations are not only frowned upon but actually eliminated, so far as may be. Jews, for example, appear heavily represented in the upper mastheads of all the major law reviews. (They do on college papers, too, but that involves other issues of motivation and selection.) A great camaraderie, sometimes of a kidding and sometimes of a tacit sort, appears to develop on the reviews between the Jewish and the non-Jewish members. In what is left of their time away from school and books, sociability is often a duplica-

* Amen. [Ed.] 
tion of the law review cliques themselves, these being based more on interest and congeniality than on fraternity-type considerations.

I do not doubt that members of law review staffs are pretty fully aware of how widely their mores diverge from those of the wider world, whether collegiate or business and professional, nor do I doubt that these "outside" considerations are sometimes brought inside, but when this happens they are felt as scandalous. The divergence from medical schools in this respect is obvious and striking. Medical school students do not edit journals in which, as not infrequently happens in the law reviews, students edit or even reject the work of their teachers. Already in the first year of medical school, the student has entered into a network of personal ties which will be decisive for his professional fate; he is judged, and judges himself, by his "personality" and connections quite as much as by his more intellectual qualities. "Personality" and connections, of course, have helped get him to medical school in the first place, whereas law school admission, like law school life, is almost devoid of these tariffs. (The mathematical formula by which Harvard Law School selects its entrants is only an extreme illustration of this pattern.) The medical school student attends a "clinical" school in the very real sense that the values which dominate the school also dominate later medical practice, though perhaps in a somewhat muted form. Medical school students, no matter how service-oriented on entrance, soon learn that they live in a patronage network whose unspoken rules will govern internships and the whole complex ladder of medical practice today. A Catholic Italian boy will have to decide, for example, whether he dare play in the big-Protestant league, because one of his teachers has taken a shine to him, or whether he should take the safer course of playing in the Catholic minor league; if he misses his bet, he may easily fall between two stools. ${ }^{x 2}$ In sum, the medical schools are "true to life" or clinical in a sense which the law schools are not; their pattern of social relations puts very little pressure on the medical community at large precisely because the students are in effect socialized as interns from the very beginning. To be sure, with respect to such issues as "socialized medicine," the medical schools controlled by full-time men may put some pressure on their students for progressive attitudes which are anathema to the medical associations, and at these same schools there is probably somewhat more impersonality than in most forms of medical practice. But on the whole, medical students do not need to face much reorientation of values when they leave medical school; their problem is

${ }_{22}$ Hall, Informal Organization of Medical Practice, I2 Can. J. Econ. \& Pol. Sci. 30 (I946); also, by the same author, The Stages of a Medical Career, 53 Am. J. Soc. 327 (I948). 
rather whether they can face treating patients without the full package of big-hospital facilities.

By contrast with this, the member of a law review staff who goes into practice suddenly confronts many of the class and ethnic barriers that his own team experience had lowered. He may enter a big non-Jewish or a big Jewish office, all of whose partners are themselves law review trained men, but all of whom are willy-nilly engaged in segregated practice. In the government, offices are unsegregated, which, however, often means largely ethnic in composition. And what is true of race is also true of sex; many large offices do not accept women as associates, though the men who run them may have worked closely with women in their law review days.

Nevertheless, the capitulation of the law review graduate to "life" is seldom complete. If he takes sex and race into account, he takes social class and religion into account much less than is the case in many other professions (e.g., architecture). It is partly this that permits the law to remain one of the careers open to talent, so that a railroad conductor's son from Cedar Falls whose college political science teacher has encouraged him to take a crack at the Harvard Law School may end up as head of a big manufacturing or utility company, or a government agency, when he would never, without connections, have made the grade within the particular company or agency hierarchy. The career of the West Virginian, John W. Davis, is an excellent instance.

Furthermore, it may well be that a comparison of legal with medical practice would show that the former has been influenced, in its recent limited inroads on the barriers of race and sex, by the law school and particularly its law review ethos, as well as by the more generalized FEPC type of pressure. Certainly when, in the Christmas holidays before graduation, law students looking for jobs are confronted with the ethnic "facts of life," they return to their law review jobs with some uneasiness, and they may welcome bar association and other activities in which the old law review camaraderies are to some extent restored. This may be one source of the fact that Italians, Jews, and women seem of late years to have been finding jobs in the big offices, though these are understandably reluctant to duplicate in their own makeup the ethnic composition, often so heavily Jewish, of the law reviews from which they draw recruits.

If I am right in these suggestions, the law attracts people who can stand a certain amount of impersonality and who are trained to be objective, in the sense of being relevant and orderly. The very "ivory-towerism" for which the law schools are often attacked allows them to emphasize tech- 
niques which are relatively unclinical. The law student, and especially the law review student, does not encounter clients and is therefore not likely to be judged for what we might call his "briefcase manner." ${ }^{\prime 3}$ The whole drift of the law is, in this sense, democratic, competitive, and impersonal. The law reviews put pressure on the profession, and the profession in turn puts pressure on the society.

Let it not be assumed that I am convinced this pressure is a good thing. Its concomitant is the rather scarifying emphasis on grades which is characteristic of law schools, for if the law review is a stepping stone to a high position, the stakes are more than a penny a point of average. Nor can we sensibly be too self-righteous about the more nepotistic atmosphere of the medical school, unless we would just as soon be attended when sick by $\mathrm{Mr}$. Economic Man; indeed, the medical schools may conceivably be criticized as not snobbish enough but as simply typifying petty-bourgeois petty prejudice. A whole society run on the principles of the law review, in which everyone read Consumer's Reports in choosing services as well as commodities, while it would appeal to Myrdal and other radical democrats, might be a somewhat uncomfortable place, with none of the hominess provided by mild degrees of segregation and corruption. But a whole society run on the principles of the medical profession would, if anything, be even more intolerable, with guild controls dictating all choices. The tensions between these two systems of value and their two historic roots is characteristic of our modern industrial society.

The law review, then, would seem to present a kind of paradigm of impersonality combined with teamwork, to be studied in its own terms and also as a yardstick for the legal profession and, by contrast, other profes-

${ }^{13}$ In considering the social and psychological consequences of professional education, it is at least as important to examine what has not been learned as to see what has been taught in the three years at school. The removal of apprentice lawyers from law offices during those years may be more significant than the items of instruction which have been substituted. This may sound strange, but we can see the problem clearly in an analogous case. As we know, industry turns increasingly to college-trained foremen, rather than promoting from the ranks, while at the same time proclaiming that the college-bred trainee might as well get a general education in college since he'll have to learn his technology and know-how in the factory anyhow. It would seem that college serves primarily to keep him for four years from learning the (often outmoded) ways of doing things he would learn if he were in the factory; when he starts fresh he can learn newer techniques developed in the meantime, and will be less disposed to sabotage them since all are equally strange. And perhaps the need to learn fast, to justify his college training and status, will lead him to short-cuts - certainly true of the greenhorn LLB who must acquire savvy fast. But the savvy acquired fast will be different-more rationalthan the savvy acquired "the hard (clinical or 'real-life') way." Since coming to these conclusions, I regret the fact that law students do not have a better time during the three years when they are spared the mislearnings of practice. 
sions as well. Investigators would have to go on to see what the pace-setter is among the law reviews in these respects, and the degree to which different reviews represent, exaggerate, or modify the attitudes of their own law school communities. Is it only at the "national" law schools, for instance, where there is little parochialism in the topics treated by student editors, that there is little parochialism in the choice of editors? We should expect some subtle interplays between the interpretations of what is "law" at a given institution and the pattern of social relations for which the law review stands. But only careful observation can discover what the interplays are in each case, and what generalizations may be safely made about "the" law review and "the" school. 